\title{
COMPREHENSIVE MANAGEMENT OF DOG FAECES: COMPOSTING VERSUS ANAEROBIC DIGESTION
}

Martínez-Sabater, E. ${ }^{1}$, García-Muñoz, M. ${ }^{2}$, Bonete, P. ${ }^{3}$, Rodriguez, M. , Sánchez-García, F.B. ${ }^{1}$, Pérez-Murcia, M.D. ${ }^{1}$, Bustamante, M.A. ${ }^{1}$, López-Lluch, D.B. ${ }^{5}$, Moral, R. ${ }^{1}$

${ }^{1}$ Dept. of Agrochemistry and Environment, Miguel Hernandez University, EPS-Orihuela, ctra. Beniel Km 3.2, Orihuela, Alicante, 03312, Spain

${ }^{2}$ Gestión de Residuos Manchegos S.L., Av. Constitución 142, 45710-Madridejos, Toledo, Spain ${ }^{3}$ Dpto. Química Física, University of Alicante, P.O. Box 99, Alicante, E-03080, Spain ${ }^{4}$ Dpto. Ingeniería Química, University of Alicante, P.O. Box 99, Alicante, E-03080, Spain ${ }^{5}$ Dept. of Agrienvironmental Economics, Universidad Miguel Hernández, Spain

Corresponding author: M.A. Bustamante E-mail address: marian.bustamante@umh.es 


\begin{abstract}
The objective of this work was to study the possibilities to manage and recycle dog faeces (DF) using biological processes, using two approaches: composting (C) and anaerobic digestion (AD). Thus, different experiments have been carried out: i) two laboratory/pilot scale experiments (selfheating and composting tests) and one, on a commercial scale; ii) two AD experiments. In both approaches, municipal waste such as the organic fraction of municipal solid waste (OMSW) and urban pruning waste $(\mathrm{GW})$ were used as co-substrates. The results obtained regarding the optimization of the composting process indicated that the best strategy was the use of a 1:2 ratio of DF, a 1:4 ratio of OMSW, and a 1:4 ratio of GW, according to the thermal parameters studied (temperature and cumulative quadratic exothermic index $\left(\mathrm{EXI}^{2}\right)$ ), and the quality of the compost obtained. A potentially limiting factor of the process was the high salinity of the DF waste. In addition, AD experiments were performed on DF, OMSW, and GW wastes in controlled anaerobic systems at a laboratory scale. In these experiments, the biogas production obtained was $229 \mathrm{~mL}$ biogas/g total solids for the DF residue, $248 \mathrm{~mL}$ biogas/g total solids for $\mathrm{GW}$, and $263 \mathrm{~mL}$ biogas/g total solids for OMSW. The co-digestion yields a clear improvement in the efficiency of the process against the use of a single residue, increasing the production of biogas by up to $27 \%$ with respect to that of the DF waste alone during the first 25 days of $\mathrm{AD}$. The results obtained with these procedures have shown the possibilities to add value to this waste in an urban context where the circular economy represents an increasingly favourable scenario, including the generation of fertilisers and/or energy at a local scale, provided that the collection of dog faeces is optimized.
\end{abstract}

Keywords: dog excrements; organic fraction of municipal solid waste; urban pruning waste; biogas, quadratic exothermic index $\left(\mathrm{EXI}^{2}\right)$; compost quality. 


\section{Introduction}

The problems related to the generation and management of dog faeces (DF) and the associated environmental contamination have largely been overlooked and, surprisingly, relatively few publications related with the management of dog faeces are available (Okoroigwe et al., 2014;

Okin, 2017). The increasing generation of waste from dog faeces can lead to health and environmental problems, especially in urban areas, since these wastes are carriers of a large population of bacteria and pathogens (Okoroigwe et al., 2014). Taylor (2004) estimated that a single dog produces daily an average of $0.34 \mathrm{~kg}$ of faeces. The estimation for Europe is lower, $140 \mathrm{~g}$, due to the greater abundance of small dogs. The quantification of canine waste is associated with censuses. As an example, the dog census in Spain is around 5.4 million dogs with an estimated generation of solid waste of between 100 and 200,000 tonnes per year, on a dry weight basis. It is estimated that in Europe there are around 41 million dogs with a generation of fresh solid waste of between 0.8 and 1.6 million tonnes per year, and only in the United States it is estimated that dogs produce approximately 10 million tonnes of fresh waste annually (ANFAAC, 2018; Brinton and Storms, 2004). Moreover, there is no specific regulation for the management of this type of organic waste, but the excrement is considered urban waste and, therefore, its usual destination is the municipal container for generic waste, for later disposal in landfill. Therefore, a treatment is necessary to manage and reduce the pathogenic charge in these organic wastes. Thus, the presence in dog waste of high amounts of the macronutrients essential for plants orientates its processing towards composting or anaerobic digestion. Dog excrement contains an average of $0.7 \%$ nitrogen, $0.25 \% \mathrm{P}_{2} \mathrm{O}_{5}$, and $0.02 \% \mathrm{~K}_{2} \mathrm{O}$ (fresh weight basis); in comparison, fresh cattle manure contains $40 \%$ more nitrogen, the same amount of $\mathrm{P}_{2} \mathrm{O}_{5}$, and $1 / 20$ the amount of $\mathrm{K}_{2} \mathrm{O}$ (Nemiroff and Patterson, 2007). This material contains an excess of total nitrogen $\left(\mathrm{N}_{\mathrm{T}}\right)$ with respect to total organic carbon (TOC), so that aerobic or anaerobic self-degradation will not occur autonomously and it is necessary to mix it with other, carbon-rich waste in processes of co-composing or co-digestion (Nemiroff and Patterson, 2007; Okoroigwe et al., 2010). 
Composting has proven to be an efficient technique in the reduction of pathogenic microorganisms in different organic wastes, since temperatures $>55^{\circ} \mathrm{C}$ are easily reached during the thermophilic stage of the process (Meng et al., 2018; Gavilanes-Terán et al., 2016; Bernal et al., 2009; SuárezEstrella et al., 2007). Very little information is available concerning the composting of this organic waste. Thus, Nemiroff and Patterson (2007) composted dog waste in an experiment developed in Alaska, due to the conditions of this area (high generation of this type of waste and small area of appropriate land available for its application). Moreover, USDA (2005) reported that the composting of dog faeces might be a suitable option for its subsequent use in revegetation and landscaping. Additionally, the efficiency of the management of dog faeces by composting may be enhanced with the use of compostable plastic bags instead of polyethylene or "oxo"-degradable polyethylene ones, due to the low degradability of these materials under industrial composting conditions, as it was reported by Musioł et al. (2017). This aspect also involves the implication of dog owners, with the adoption of new practices to enhance the sustainability of the later management of this type of wastes. However, as it was reported by Guerin (2001) in a study about the challenges and barriers to adopt innovative and sustainable land use practices, generally not all recommended practices, designed to enhance sustainability, are likely to be adopted, and this aspect should be also considered in the implementation of the management options proposed in this study Similarly, anaerobic digestion (AD) can also constitute a viable treatment to reduce the pathogenic charge of this type of waste, additionally obtaining a renewable energy, biogas, and the digestate, a by-product of the process rich in nutrients that can be used as an agricultural amendment. This process usually uses lignocellulosic biomass (easily degradable) as raw material, such as food waste, sludge, and different types of animal manure (Lin et al., 2018). There are many studies on the $\mathrm{AD}$ of livestock waste; however, there are very few studies regarding AD of dog faeces. ManyiLoh et al. (2014) and Okoroigwe et al. (2010) carried out different experiments of anaerobic digestion of dog faeces, using carbon-rich materials as co-substrates, both reporting a decrease in 
the number of bacteria and pathogens during the process. In addition, Demirel et al. (2010) reported the in situ treatment of dog waste with $\mathrm{AD}$ to obtain a local source of energy.

Therefore, the main objective of this work was to compare the feasibility of two biological treatments (composting and anaerobic digestion) to manage and recycle canine excrements, using different optimization protocols for each treatment. In both treatments, the same co-substrates (organic fraction of municipal solid waste (OMSW) and urban pruning waste (GW)) were used to enhance the process development. For the composting treatment, two laboratory/pilot scale experiments (self-heating and composting) and one on a commercial scale were performed. For AD, two experiments were developed to evaluate the biogas production of all the organic wastes considered in the process (DF, OMSW, GW and cellulose) and to study the co-digestion process of DF mixed with these wastes.

\section{Material and methods}

\subsection{Experimental design}

The organic wastes used in the experiments of co-composting and anaerobic digestion were dog faeces waste (DF) mixed with two co-substrates, the organic fraction of municipal solid waste (OMSW) and urban pruning waste (GW). DF was collected from an animal protection charity placed in Orihuela (Alicante, Spain); OMSW come from the selective collection at source of Carricola (Valencia, Spain) and GW was the green waste derived from the pruning activities of urban gardening of the city of Orihuela (Alicante, Spain). The main characteristics of these organic wastes are shown in Table 1.

\subsubsection{Composting procedure}

Three co-composting strategies were established on consecutive experimental scales:

1. Experiment C1: Self-heating tests using Dewar vessels. 
2. Experiment C2: Pilot scale composting.

3. Experiment C3: Semi-industrial composting

In Experiment C1 (self-heating in Dewar vessels), three mixtures were established in the following proportions on a dry matter basis:

- C1B: 50\% DF + 50\% OMSW

- C1C: $50 \% \mathrm{DF}+50 \% \mathrm{GW}$

- C1D: 50\% DF + 25\% OMSW + 25\% GW

The mixtures were developed in triplicate in $5 \mathrm{~L}$ Dewar vessels, for 168 hours, measuring the internal and environmental temperature every 15 minutes by means of a PASCO ${ }^{\circledR}$ system temperature sensor. Every 12 hours, the Dewar vessel was aerated for 2 minutes to assure the aerobic conditions.

In the composting experiment at pilot scale (Experiment C2), a composting mixture (Pile C2) was tested in triplicate in $350 \mathrm{~L}$ thermocomposters. The proportions of the mixture, on a fresh matter basis were the following:

- Pile C2: 64.9\% DF + 18.3\% OMSW + 16.8\% GW

In this mixture, the ventilation was supplemented from the base of the thermocomposter by periodic manual turnings, forming the piles in a sandwich system. Daily measurements of temperature and humidity were monitored, maintaining the humidity in values between $40 \%$ and $70 \%$, especially in the bio-oxidative phase when the loss of water by evaporation was greater. In this experiment, the cumulative quadratic exothermic index $\left(\mathrm{EXI}^{2}\right)$ was determined according to Vico et al. (2018). The next step in the optimization of the recycling of the dog faeces was carried out at a semiindustrial scale (Experiment C3). Two composting mixtures (about $700 \mathrm{~kg}$ ) were composted in the 
composting plant of GESREMAN S.L., located in Madridejos (Toledo, Spain), using a mechanically turned pile. In these piles, the humidity was also controlled to keep it at values between $40-70 \%$. The proportions of these mixtures were the following (on a fresh matter basis):

- Pile C3A: 58.8\% OMSW + 23.5\% GW + 17.7\% DF

- Pile C3B: 82.4\% OMSW + 17.6\% DF

In the Experiments C2 and C3, samples from the beginning and end of the process (maturity) were collected by mixing seven sub-samples from seven sites of the composting pile, from the whole profile (from the top to bottom). Each sample was divided into two fractions: one was air-dried and ground to $0.5 \mathrm{~mm}$ for analysis and the other was immediately frozen and kept for later determinations. All the analytical determinations were performed in triplicate.

\subsubsection{Anaerobic digestion procedure}

In this experiment, two methodological approaches were used:

AD1) Anaerobic digestion of waste materials: 100\% DF + inoculum, 100\% GW + inoculum, 100\% OMSW + inoculum, 100\% cellulose + inoculum (as a C source, established as a control), and only inoculum (control).

AD2) Anaerobic co-digestion/biomethanization: Five ternary mixtures were made using DF, GW, and OMSW. Their respective fresh matter percentages were:

Mixture 1: 33.3/33.3/33.3

Mixture 2: 16.7/66.7/16.7

Mixture 3: 16.7/16.7/66.7

Mixture 4: 66.7/16.7/16.7

Mixture 5: 83.3/8.3/8.3. 
The determination of the biogas formation potential was carried out according to Angelidaki et al. (2009). Briefly, in a sealed glass reactor at $35^{\circ} \mathrm{C}$, a known amount of the sample to be studied was incubated with an inoculum containing the biomass that will undergo the anaerobic digestion and the mineral medium necessary for the growth of the biomass. Sewage sludge from a wastewater treatment plant was used as the inoculum source. The $\mathrm{pH}$ of the inoculum was 7.60; the content of total solids was $2.88 \mathrm{~g} / \mathrm{L}, 61.5 \%$ being volatile solids; the ammonium concentration was $1656 \mathrm{mg} / \mathrm{L}$ and those of acetic acid and butyric acid were 23 and $25 \mathrm{mg} / \mathrm{kg}$, respectively.

The assays consisted of the measurement, at different times, of the pressure of the biogas generated during the incubation (at $35^{\circ} \mathrm{C}$ and in triplicate) of the above described inoculum, previously diluted in water (water/inoculum: 3/2). Each digester (250 mL) contained $150 \mathrm{~mL}$ of the inoculum solution, purged with nitrogen for 1 minute $(1 \mathrm{~L} / \mathrm{min})$ to remove any oxygen, and, for each of the different samples studied, an amount equivalent to $0.100 \mathrm{~g}$ of carbon. The production of biogas was determined by measuring the pressure of the gas generated and stored in the head of the digester over different intervals of time; it was corrected for the biogas generated by the inoculum. The biogas pressure was measured at $35^{\circ} \mathrm{C}$, the excess pressure generated during the degradation was then eliminated, using a cannula, and subsequently the contents of each digester were mechanically stirred for 10 seconds.

\subsection{Analytical methods}

Electrical conductivity (EC) and $\mathrm{pH}$ were determined in a water-soluble extract $(1: 10, \mathrm{w} / \mathrm{v})$. Organic matter (OM) was evaluated by determining the loss-on-ignition at $430{ }^{\circ} \mathrm{C}$ for 24 hours (Navarro et al., 1993). Total nitrogen ( $\left.\mathrm{N}_{\mathrm{T}}\right)$ and total organic carbon (TOC) were determined by automatic microanalysis (Navarro et al., 1991), as were the organic carbon extractable with $0.1 \mathrm{M}$ $\mathrm{NaOH}(\mathrm{Cex})$ and the fulvic acid-like carbon (Cfa), the later after the precipitation of the humic acidlike carbon (Cha) of the $\mathrm{NaOH}$ extract at pH 2.0 (Sánchez-Monedero et al., 1996). Cha was calculated by subtracting Cfa from Cex. The water-soluble polyphenols (WSP) were determined, 
according to the modified Folin Ciocalteu method, in an aqueous extract (1:20, w/v) (Beltrán et al., 1999) and the germination index (GI) was calculated using results obtained with seeds of Lepidium sativum L. (Zucconi et al., 1981). After digestion with $\mathrm{HNO}_{3} / \mathrm{HClO}_{4}$, the $\mathrm{P}$ was evaluated colorimetrically as molybdovanadophosphoric acid, and the $\mathrm{Na}$ and $\mathrm{K}$ were determined by flame photometry. In addition, the cation exchange capacity (CEC) was evaluated using $\mathrm{BaCl}_{2}$ triethanolamine, according to the method of Lax et al. (1986).

\subsection{Statistical analysis}

An ANOVA using one factor (initial time versus final time) was performed for each assay. In the cases in which the F-ANOVA showed statistical significance, the Tukey-b test was used as a posthoc test to evaluate the differences between specific means; in the tables, letters were used to indicate differences significant at the 95\% probability level $(\mathrm{p}<0.05)$. The IBM SPSS version 25 statistical package was used.

\section{Results and discussion}

\subsection{Composting experiment}

\section{a) Experiment C1 (Self-heating assay)}

In the initial assay using Dewar vessels $(\mathrm{C} 1)$, the $\mathrm{TOC} / \mathrm{N}_{\mathrm{T}}$ ratio of the initial mixtures $(\mathrm{C} 1 \mathrm{~B}, \mathrm{C} 1 \mathrm{C}$, and C1D) were 16.5, 25.8, and 21.1, respectively. These values were similar to that obtained for the initial mixture of dog faeces and wood chips by Nemiroff and Patterson (2007). An increase in the initial TOC/ $\mathrm{N}_{\mathrm{T}}$ ratio of DF was observed when using a greater proportion of the more bulking agent $\mathrm{GW}$; in this case, the best cumulative quadratic exothermic index $\left(\mathrm{EXI}^{2}\right)$ was obtained (Figure 1). The use of OMSW did not improve the properties of the DF at the beginning of the biotechnological process due to its low $\mathrm{TOC} / \mathrm{N}_{\mathrm{T}}$ ratio. However, the potential value of the OMSW 
fraction at the levels of production, synergy, and nutrient content make it interesting to carry out trials involving the elaboration of ternary mixtures. Therefore, taking into account the results obtained in the Experiment C1, the next step in the optimization of the processing of the DF was a composting assay on a scale of thermocomposter (Experiment C2), using a ternary mixture of these three residues.

\section{b) Experiment C2 (Pilot scale composting)}

Temperatures above $55^{\circ} \mathrm{C}$ are necessary to eliminate pathogenic microorganisms during the composting process (Bernal et al., 2009). In this case, a sudden heating of the mixture was observed as a consequence of the proliferation of microorganisms, reaching the maximum temperature $\left(63.2^{\circ} \mathrm{C}\right)$ on day 4 (Figure 2). A rapid increase in temperature was also observed by Paredes et al. (2015) for the composting of mixtures of goat and rabbit manures, the thermal profile during the bio-oxidative phase being similar in both cases. Nemiroff and Patterson (2007) also reported temperature values greater than $50^{\circ} \mathrm{C}$ during three consecutive days in an experiment of composting of dog excrement. Turning was carried out after 15 days to favour the homogenization of the mixture; after this, the temperature value observed prior to turning was then recovered, indicating good natural aeration and a homogeneous mixture. On day 38 another turning was made; at this point, a slight increase in temperature, and therefore in activity, was observed. Subsequently, no significant increases in the temperature of the mixture were observed with respect to that of the environment, and the bio-oxidative phase was concluded on day 53. After this, the compost was allowed to mature for a month. The period of bio-oxidative activity was prolonged considering the environmental conditions and the scale of the work, in a thermocomposter, which suggests that there would be a high level of degradation if performed at commercial scales. The values of the parameters number of days of bio-oxidative phase/number of days with temperature values $>40^{\circ} \mathrm{C}$, $\mathrm{EXI}^{2}$, and $\mathrm{EXI}^{2} /$ number of days of bio-oxidative phase were 33, 14150, and 295, respectively, 
comparable to other urban waste composting processes (Vico et al., 2018, Jara-Samaniego et al., 2017).

In this experiment, the initial mixtures did not have particularly high $\mathrm{pH}$ values (Table 2). In fact, these values are lower than those observed in other works where different types of manures were composted (Rich et al., 2018; Bustamante et al., 2008; Paredes et al., 2015). By the end of the process a significant increase in $\mathrm{pH}$ had taken place, associated with the enrichment in exchange bases and the loss of volatile fatty acids. This increase in $\mathrm{pH}$ is commonly observed in the composting of manures with plant residues (Gavilanes-Terán et al., 2016; Benito et al., 2009). According to previous studies, the $\mathrm{pH}$ of composts obtained from dog faeces was close to neutrality (Nemiroff and Patterson, 2007). Values of $\mathrm{pH}$ in the range 6.0-8.5 are considered suitable for compost (Bustamante et al., 2010; Hogg et al., 2002).

The EC and the N content increased significantly during the composting process due to the mineralisation of the $\mathrm{OM}$ and the relative concentration of ions due to the loss of pile mass (Bustamante et al., 2008). In addition, the compost from dog faeces showed high contents of N, P, and $\mathrm{K}$, and had a high salinity, so it is recommended to mix it in a 1:4 ratio with soil before its application (Rippy et al., 1997; Freeborne, 1994; Nemiroff and Patterson, 2007).

The contents of OM and TOC decreased significantly during the composting process as a consequence of the mineralisation of OM by microorganisms (Bernal et al., 2009). In this composting experiment, the OM content decreased from $66.1 \%$ to $51.5 \%$. In this case, the percentage of $\mathrm{OM}$ in the final compost was higher than the limits established for compost by the European guidelines and the Spanish legislation (OM > 15\% (European Commission, 2014); OM > 35\% (BOE, 2013)) (Paredes et al., 2015). Similar OM values were observed by Idrovo-Novillo et al. (2018) when composting different poultry manures with flower waste.

The TOC/ $\mathrm{N}_{\mathrm{T}}$ ratio decreased significantly, indicating good mineralisation of the OM, during the composting process. In the Experiment C2, this ratio was lower since in this case there was a slight increase in $\mathrm{N}_{\mathrm{T}}$ in the final compost with respect to the initial mixture, while in the piles $\mathrm{N}_{\mathrm{T}}$ had 
decreased at the end of the process. Generally, $\mathrm{N}_{\mathrm{T}}$ increases during the composting process due to the concentration effect, while most of the $\mathrm{N}$ losses that occur during composting when animal manure is used are due to the volatilization of ammonium (Bernal et al., 2009).

The germination index (GI) is a biological test that is very sensitive to the inhibitory effects of phytotoxins (phenols, fatty acids, ammonia, etc.) resulting from the processes of mineralisation of OM. According to the method proposed by Zucconi et al. (1981), compost is mature when GI > $50 \%$. In this case, a GI of $85 \%$ was obtained, indicating no phytotoxic effects of the final material (Table 3).

The CEC is a parameter indicative of the degree of quality and maturity of the final compost obtained. The CEC and CEC/TOC values and the GI were high and, indicating a high degree of maturity and quality and the absence of phytotoxic effects in the final compost (Table 3). A content of humic and fulvic acids equal to $5.2 \%$ of the weight of the final product was obtained a value comparable to those obtained in green and municipal waste composts, although somewhat lower than those obtained for agri-food compost (Bustamante et al. al., 2010).

Finally, considering the fertilising richness, expressed as the $\mathrm{N}-\mathrm{P}_{2} \mathrm{O}_{5}-\mathrm{K}_{2} \mathrm{O}$ content, a value in fertiliser units of 2.4-8.7-2.1 was obtained, expressed as a percentage on a dry matter basis. If a moisture content of $30 \%$ is considered in the product, its fertiliser value would be 1.7-6.1-1.5, similar to that of the compost obtained from livestock manure by Eckhardt et al. (2018). Therefore, the high CEC values obtained, the absence of phytotoxic effects, and the fertiliser value of the final compost produced at the pilot scale (Experiment C2) together justified a further step in the optimization of the composting process with the development of two piles on a commercial scale (Experiment C3).

\section{c) Experiment C3 (Semi-industrial composting)}

In this Experiment, the EC and the P content decreased at the end of the process, probably due to the leaching of salts by irrigation and rain. This decrease in EC during composting has been 
observed in other works (Paredes et al., 2015; Gavilanes-Terán et al., 2016). The EC values of the final composts indicate that the salinity was a little higher than the limit value considered tolerable by plants with an average sensitivity to salinity (Lasaridi et al., 2006).

The final content of OM was over 30\%, a value comparable with those of other composts produced from livestock waste (Gavilanes-Terán et al., 2016). The piles had a very low initial TOC/ $\mathrm{N}_{\mathrm{T}}$ ratio due to the presence of DF, which is very rich in $\mathrm{N}$ (Table 2). There was a high loss of $\mathrm{N}$ in the system, so it would be advisable to formulate mixtures with a higher percentage of bulking agent (Bernal et al., 2009). The GI values obtained were below 50\%, probably due to the potentially limiting factors of the process that were detected, such as the high salinity of the final compost, which strongly depends of the characteristics of the DF waste used.

The $\mathrm{N}-\mathrm{P}_{2} \mathrm{O}_{5}-\mathrm{K}_{2} \mathrm{O}$ fertiliser capacity of the commercial composts was: 1.6-1.1-1.0 for the ternary compost (C3A) and 1.8-1.5-1.1 for C3B, significantly lower than in the C2 phase, although similar to that obtained by other authors using poultry manure (Gavilanes-Terán et al., 2016; Leconte et al., 2009).

\subsection{Anaerobic digestion experiment}

In the mono-ingredient biomethanization assay (AD1), a biogas production of $229 \mathrm{~mL} / \mathrm{g}$ total solids (TS) was obtained for DF (Table 4). For DF, the value coincided almost exactly with the average value of the experiments (76.2\% methane richness), GW being the residue with the highest percentage of methane (Figure 3).

The production of biogas was higher for both GW and OMSW than for DF, so different mixtures were made using these wastes with the objective of improving the efficiency of the process In the second biomethanization assay (AD2), all the mixtures studied, except M3, gave improved biogas production (Table 4), M1 and M5 giving the highest values (279 and $291 \mathrm{~mL} / \mathrm{g}$ TS, respectively). Mixtures M2 and M4 showed the highest percentage values of $\mathrm{CH}_{4}(78.6 \%$ and $79.2 \%$, respectively), so the presence of garden waste seemed to promote greater biogas richness. 
An increase in the production of biogas and methane due to the mixing of the waste from dog faeces with plant waste was also observed in the study of Okoroigwe et al. (2010). According to these authors, the contribution of methanogenic bacteria in the waste derived from dog faeces can increase the metabolic decomposition of cellulose in plant material, and the combination of microorganisms present in both these materials, such as Bacteroides sp., could contribute to a greater production of biogas.

Although the concept has been put into practice, as described in the literature (Okin, 2017; Nemiroff and Patterson, 2007), it is difficult to find specific biogas production values for canine faeces. Okoroigwe et al. (2014) obtained values of $28.6 \mathrm{~L} / \mathrm{kg}$ of fresh matter (113 L/kg total solids, $140 \mathrm{~L} / \mathrm{kg}$ volatile solids) for the anaerobic fermentation of canine faeces over a period of 59 days. These same authors (2010) studied the codigestion with herbaceous residues and cattle manure, obtaining biogas yields - at 50 days - of 178, 218, and $297 \mathrm{~L}$ for $5 \mathrm{~kg}$ of canine faeces alone, $5 \mathrm{~kg}$ of canine faeces plus $5 \mathrm{~kg}$ of herbaceous waste, and $4 \mathrm{~kg}$ of canine faeces plus $6 \mathrm{~kg}$ of cow manure, respectively.

\section{Conclusions}

The obtaining of potential value-added products from dog faeces waste, such as compost and biogas, and the efficiencies and viability of both processes have been evaluated and compared in this study. The thermal profile, the lack of phytotoxicity, and the fertiliser value obtained by optimization of the composting process indicated that the best alternative was the use of ternary mixtures for composting. Factors that could potentially limit the process (high salinity) were detected in the piles prepared at semi-industrial scale. The significant $\mathrm{N}$ loss found in the composting system makes necessary the use of higher percentages of bulking agent in the composting mixtures. Concerning the anaerobic digestion experiment, DF waste yielded a biogas production of $229 \mathrm{~mL} / \mathrm{g}$ TS. An evident improvement in the efficiency of the process was produced when using mixtures of this waste with urban prunings and the organic fraction of municipal solid 
waste. The mixtures with the highest percentages of DF waste and prunings seemed to enhance the biogas richness during the first 25 days of anaerobic digestion. Therefore, the results obtained have shown the viability of large-scale dog waste composting programs, which can be successfully implemented in urban environments, providing an alternative to partially reduce the quantity of solid organic waste sent to municipal landfills. In this sense, these results also highlight the need of implying dog owners in the improvement of dog faeces management, with the use of compostable plastic bags instead of polyethylene or "oxo"-degradable polyethylene ones to collect dog faeces. Canine faeces are not commonly used to produce biogas, but the results obtained in this study showed that the mixtures of this waste with material of plant origin may increase their potential to generate biogas, to values that are even equal to those of livestock waste. Therefore, the results obtained in this research are key to the design of integrated models for the recycling of different sources of organic matter, such as canine excrements, in a municipal context.

\section{Acknowledgments}

The authors wish to thank the company GESREMAN and D. Manuel López de la Nieta Hernández that collaborated in the innovation project DF 2.0: Introducción de herramientas TIC en equipamiento urbano para mascotas dentro de un nuevo escenario impulsado por la economía circular, carried out with the help of the Adelante-Innova Program of the Regional Government of Castilla-La Mancha (file number 13/16/CO/1/003).

\section{References}

ANFAAC, 2018. Asociación nacional de fabricantes de alimentos para animales de compañía: Censo de mascotas. http://www.anfaac.org/macromagnitudes-del-sector/ [in Spanish] (accessed 30 October 2018). 
Angelidaki, I., Alves, M., Bolzonella, D., Borzacconi, L., Campos, J.L., Guwy, A.J., Kalyuzhnyi, S., Jenicek, P., van Lier, J.B., 2009. Defining the biomethane potential (BMP) of solid organic wastes and energy crops: a proposed protocol for batch assays. Water Sci. Technol. 59 (5), 927-934. Beltrán, F.J., García-Araya, J.F., Álvarez, P.M., 1999. Wine distillery wastewater degradation. 1. Oxidative treatment using ozone and its effect on the wastewater biodegradability. J. Agric. Food Chem. 47, 3911-3918.

Benito, M., Masaguer, A., Moliner, A., Hontoria, C., Almorox, J., 2009. Dynamics of pruning waste and spent horse litter co-composting as determined by chemical parameters. Bioresour. Technol. 100, 497-500.

Bernal, M.P., Alburquerque, J.A., Moral, R., 2009. Composting of animal manures and chemical criteria for compost maturity assessment: A review. Bioresour. Technol. 100, 5444-5453. BOE, 2013. Real Decreto 506/2013, de 28 de junio, sobre productos fertilizantes. Boletín Oficial del Estado 164, 51119-207 [in Spanish].

Brinton, W.F., Storms, P.H., 2004. Microbiological test qualities of composted manures and yardwastes. World Congress Organic Food, Michigan State University, March 29-31.

Bustamante, M.A., Paredes, C., Marhuenda-Egea, F.C., Pérez-Espinosa, A., Bernal, M.P., Moral, R., 2008. Co-composting of distillery wastes with animal manures: Carbon and nitrogen transformations in the evaluation of compost stability. Chemosphere 72, 551-557.

Bustamante, M.A., Suárez-Estrella, F., Torrecillas, C., Paredes, C., Moral, R., Moreno, J., 2010. Use of chemometrics in the chemical and microbiological characterization of composts from agroindustrial wastes. Bioresour. Technol. 101, 4068-4074.

Demirel, B., Scherer, P., Orhan, Y., Turgut, T.O., 2010. Production of methane and hydrogen from biomass through conventional and high-rate anaerobic digestion processes. Crit. Rev. Environ. Sci. Tech. 40, 116-146. 
Eckhardt, D.P., Redin, M., Almeida Santana, N., De Conti, L., Dominguez, J., Jacques, R.J.S., Antoniolli, Z.I., 2018. Cattle manure bioconversion effect on the availability of nitrogen, phosphorus, and potassium in soil. Rev. Bras. Cienc. Solo 42, e0170327.

European Commission, 2014. End-of-waste criteria for biodegradable waste subjected to biological treatment (compost and digestate): Technical proposals. http://ipts.jrc.ec.europa.eu/publications/pub.cfm?id=6869 (accessed 25 April 2014). Freeborne, J., 1994. Composting dog manure in Fairbanks. BioCycle 35 (1), 70-71.

Gavilanes-Terán, I., Jara-Samaniego, J., Idrovo-Novillo, J., Bustamante, M.A., Moral, R., Paredes, C., 2016. Windrow composting as horticultural waste management strategy - a case study in Ecuador. Waste Manage. 48, 127-134.

Guerin, T.F., 2001. Why sustainable innovations are not always adopted. Resour. Conserv. Recy. 34, 1-18.

Hogg, D., Favoino, E., Centemero, M., Caimi, V., Amlinger, F., Devliegher, W., Brinton, W., Antler, S., 2002. Comparison of compost standards within the EU, North America and Australia, The Waste and Resources Programme (WRAP), Oxon.

Idrovo-Novillo, J., Gavilanes-Terán, I., Bustamante, M.A., Paredes, C., 2018. Composting as a method to recycle renewable plant resources back to the ornamental plant industry: Agronomic and economic assessment of composts. Process Saf. Environ. 116, 388-395.

Jara-Samaniego, J., Perez-Murcia, M.D., Bustamante, M.A., Perez-Espinosa, A., Paredes, C., Lopez, M., Lopez-Lluch, D.B., Gavilanes-Terán, I., Moral, R., 2017. Composting as sustainable strategy for municipal solid waste management in the Chimborazo Region, Ecuador: suitability of the obtained composts for seedling production. J. Clean. Prod. 141, 1349-1358.

Lasaridi, K., Protopapa, I., Kotsou, M., Pilidis, G., Manios, G., Kyriacoua, A., 2006. Quality assessment of composts in the Greek market: The need for standards and quality assurance. J. Environ. Manage. 80, 58-65. 
Lax, A., Roig, A., Costa, F., 1986. A method for determining the cation-exchange capacity of organic materials. Plant Soil 94, 349-355.

Leconte, M.C., Mazzarino, M.J., Satti, P., Iglesias, M.C., Laos, F., 2009. Co-composting rice hulls and/or sawdust with poultry manure in NE Argentina. Waste Manag. 29, 2446-2453.

Lin, L., Xu, F., Ge, X., Li, Y., 2018. Improving the sustainability of organic waste management practices in the food-energy-water nexus: A comparative review of anaerobic digestion and composting. Renew. Sust. Energ. Rev. 89, 151-167.

Manyi-Loh, C.E., Mamphweli, S.N., Meyer, E.L., Okoh, A.I., Makaka, G., Simon, M., 2014. Inactivation of selected bacterial pathogens in dairy cattle manure by mesophilic digestion (Balloon type digester). Int. J. Environ. Res. Public Health. 11, 7184-7194.

Meng, X., Liu, B., Xi, C., Luo, X., Yuan, X., Wang, X., Zhu, W., Wang, H., Cui, Z., 2018. Effect of pig manure on the chemical composition and microbial diversity during co-composting with spent mushroom substrate and rice husks. Bioresour. Technol. 251, 22-30.

Musioł, M., Rydz, J., Janeczek, H., Radecka, I., Jiang, G., Kowalczuk, M., 2017. Forensic engineering of advanced polymeric materials Part IV: Case study of oxo-biodegradable polyethylene commercial bag - Aging in biotic and abiotic environment. Waste Manage. 64, 20-27. Navarro, A.F., Cegarra, J., Roig, A., Bernal, M.P., 1991. An automatic microanalysis method for the determination of organic carbon in wastes. Commun. Soil Sci. Plant 22, 2137-2144. Navarro, A.F., Cegarra, J., Roig, A., García, D., 1993. Relationships between organic matter and carbon contents of organic wastes. Bioresour. Technol. 44, 203-207.

Nemiroff, L., Patterson, J., 2007. Design, testing and implementation of a large-scale urban dog waste composting program. Compost Sci. Util. 15, 237-242.

Okin, G.S., 2017. Environmental impacts of food consumption by dogs and cats. PLoS ONE 12(8): e0181301.

Okoroigwe, E.C., Ibeto, C.N., Ezema, C.G., 2014. Experimental study of anaerobic digestion of dog waste. Sci. Res. Essays 9 (6), 121-127. 
Okoroigwe, E.C., Ibeto, C.N., Okpara, C.G., 2010. Comparative study of the potential of dog waste for biogas production. Trends Appl. Sci. Res. 5 (1), 71-77.

Paredes, C., Pérez-Murcia, M.D., Pérez-Espinosa, A., Bustamante, M.A., Moreno-Caselles, J., 2015. Recycling of two-phase olive-mill cake "alperujo” by co-composting with animal manures. Commun. Soil Sci. Plant Anal. 46, 238-247.

Rich, N., Bharti, A., Kumar, S., 2018. Effect of bulking agents and cow dung as inoculant on vegetable waste compost quality. Bioresour. Technol. 252, 83-90.

Rippy, A., Gleason, M., Ash, A., Willingham, S., 1997. Composting dog waste in interior Alaska. Fairbanks soil and water district, study details, CWA Section 319 Progress Report, Project: 8FY92-AK, 14 pp.

Sánchez-Monedero, M.A., Roig, A., Martínez-Pardo, C., Cegarra, J., Paredes, C., 1996. A microanalysis methods for determining total organic carbon in extracts of humic substances. Relationships between total organic carbon and oxidable carbon. Bioresour. Technol. 57, 291-295. Suárez-Estrella, F., Vargas-García, M.C., López, M.J., Capel, C., Moreno, J., 2007. Antagonistic activity of bacteria and fungi from horticultural compost against Fusarium oxysporum f. sp. melonis. Crop Prot. 26, 46-53.

Taylor, L., 2004. Poop, scoop and compost: proposal to explore the feasibility of composting dog waste in public parks. Vancouver, Canada: national coalition for people and dogs. Handout, 1-7. USDA, 2005. United States Department of Agriculture, National Resources Conservation Service. Backyard Conservation Tip Sheet.

Vico A., Pérez-Murcia, M.D., Bustamante, M.A., Agulló, E., Marhuenda-Egea, F.C., Sáez, J.A., Paredes, C., Pérez-Espinosa, A., Mora,l R., 2018. Valorization of date palm (Phoenix dactylifera L.) pruning biomass by co-composting with urban and agri-food sludge. J. Environ. Manage. 226, 408415.

Zucconi, F., Pera, A., Forte, M., de Bertoldi, M., 1981. Evaluating toxicity of immature compost. Bio Cycle 22, 54-57. 